\title{
Modelling Socio-Spatial Change: Istanbul, Kadıköy Case
}

\author{
Aslı Ulubaş Hamurcu ${ }^{1}$ (D) Fatih Terzi ${ }^{1}$ (D)
}

Accepted: 20 April 2021 / Published online: 16 May 2021

(C) The Author(s), under exclusive licence to Springer Nature B.V. 2021

\begin{abstract}
This study aims to understand the relationship between social structure and morphological character based on a case area from Kadıköy, Istanbul, Turkey considering several independent (cultural diversity, family type, income level, ownership status) and dependent (land use type, land cover, building type, building layout, settlement type, settlement pattern, street pattern, commercial pattern) variables. Existing data is processed in two steps and analyzed by categorical regression. Results of the study show that urban character of the Kadıköy historical city center is closely related with family type, income level and cultural diversity. As this study has unique contributions in search for alternative methodologies to overcome limitations in the availability of data, it is expected to open new dimensions for further studies in social sciences and urban studies.
\end{abstract}

Keywords Socio-spatial change · Urban morphology · Categorical regression (CATREG) · Urban studies $\cdot$ Social sciences

\section{Introduction}

With the spatial turn, space is started to be regarded as a product of society. According to Marcuse (1993), society is a mixture of relations of production, consumption, income, ethnicity, gender, household composition, age and housing tenure, and all of these come together and shape/form space. Soja (1989) defines this as 'social-based spatiality'. In other terms, though space is a pre-given physical environment, the organization and the meaning of space are man-made; therefore the social relations of production are 'space-forming and space contingent' (Soja, 1980). As Soja further explains, this interaction between society and space is based on a dual interaction and called as socio-spatial dialectic. Hence, with any historical and cultural change, a new element is added or some pre-existing elements disappear as (urban) space develops (Relph, 1976). According to Davis (1950), cultural change is a longer-term change than societal change. However, as discussed by others

Aslı Ulubaş Hamurcu

ulubas@itu.edu.tr

Fatih Terzi

terzifati@itu.edu.tr

1 Department of Urban and Regional Planning, Faculty of Architecture, Istanbul Technical University, Harbiye Mah., Taşkışla Cad No: 2 Şişli, 34367 İstanbul, Turkey 
(Appelbaum, 1970; Coser, 1967; Strasser \& Randall, 1981), long is a subjective term and change in social structure might differ which makes it difficult to understand the change itself, and therefore its effect on (urban) space. In recent years, research on socio-spatial dialectic has enriched and a wide range of studies are being handled in different scales, subtopics, and case areas from different countries based on differentiating time intervals. These studies are mainly grouped under three depending on their focus of interest though they have differences in terms of scope of the theoretical framework they base their studies on and the choice of scale for analysis so that the drivers of socio-spatial change vary.

The first group of studies approaches to the topic from socio-spatial differentiation/segregation to understand and to define the social dynamics that are dominating the site selection of certain social or cultural groups within the city, in other words, the social geography. For Andersson (1998), it is important to look from a wider geographical setting to socio-spatial segregation. Instead of using a specific theoretical framework, he compares three different approaches (culturalist, cultural racism/discriminatory and structural) and comes up with a heuristic model to answer the causality issue in (ethnic) residential segregation. Similarly, Sykora (1999) emphasizes on the role of social mobility and migration followed with housing renovation and new housing construction in the case of spatial segregation. However, according to Walks (2001), the social effects of economic restructuring and occupational changes are the main drivers of change in cities. For this reason, he tests for the increased polarization, shifts in occupation, immigration and income variables, whereas, Peters and Skop (2007: 154) focus on the local scale to look for details that "confound conventional explanations of the dynamics of spatial segregation". In sum, this group of studies handles the subject of socio-spatial dialectic based on an upper scale perspective, covering the issues of wider geographical social movements and mobilities and their relationship with how cities and residential areas are being shaped/developed.

The second group of studies concentrate on urban policy as a tool for urban development and its being an arbiter for the socio-spatial formation or change. According to $\mathrm{Li}$ and $\mathrm{Wu}$ (2006), the dynamics of spatial segregation are external and mainly based on residential inequalities, in other words, regrouping of residents according to their socio-economic status, determined by policies such as ongoing housing reform and the massive increase in housing construction, which results in differentiated neighborhoods. In addition to these, Masoumi et al. (2019) claim that planning, political, and societal trends affect the neighborhood morphology which is measured by population density, centrality, formation and location of urban facilities, and configuration of street networks. On the other hand, Földi and Kovács (2014) focus on the locational preferences of both residents and investors, and determine local efforts and mechanisms as the arbiters of change in neighborhoods. For Rodríguez et al. (2001), urban policy as a tool for revitalization is not enough on its own. It is also important to reveal the important roles of emerging governance dynamics and institutions in the case of urban development. As Gaffney examines infrastructure development projects related with mega-events and tries to determine the discourse of urban development, he comes up with a result that "temporary regimes of extra-legal governance (...) permanently transform socio-space" (2010: 7). This group of studies, again similar to the first group of studies, look down on socio-spatial change from a holistic point of view and put emphasis on urban policy as an important tool for controlling/shaping/determining the change in urban space by regulating social or cultural systems and trends.

Marcinczak and Sagan (2011) claim that to understand this change, a comprehensive study is obligatory in multiscale. Hence, the third group of studies consist of those which focus on socio-spatial relations and by how urban space is being (re)shaped from a local scale. Although political and economic transformations cause changes in macro levels, 
micro-level studies reveal the dynamics behind different spatial resolutions. van Criekingen (2010) determines the understanding of multiple social class stratifications of demographic change as an important indicator for socio-spatial transformations. According to Martin (2005), academic interest in the cultural aspects of change in urban space starts with the 1990s. With the 2000s, the focus of the studies moves towards lifestyle perspective and its effects on residential choice different than that of traditional housing studies focusing on demographic and socio-economic factors until now. ÆrØ (2006) defines lifestyle as a combination of subjective patterns of orientation, preferences and cultural affiliation, whereas for Beamish et al. (2001), it is determined by household type, social class and housing value. Similarly van Ham et al. (2013) define household behavior as an important factor as they have the flexibility to choose certain urban areas (neighborhoods) to live in, and by this unlimited choice pattern by households, the population composition of neighborhoods may also change. However, based on their study about the change in culture and housing design in Turkey, Ozdemir and Gencosmanoglu (2007) claim that lifestyle or household behavior is not enough for understanding the housing design and preference on its own. The structure of families, customs, traditions, habits, and religion have also been effective in the spatial organization of the house and development of housing in Turkey. Also supported by Rapoport (1969), culture, in these terms, is the key for the variety in space formation regarding housing. Indeed, each case area or country has its own dynamics, and thus, has to be evaluated in its own circumstances despite the externalities that are also a part of this change. All in all, most of the empirical studies regarding socio-spatial change are handled in the field of housing studies and they mainly focus on certain demographic groups and their preferences in housing or residential areas in the local scale.

Thus, this study looks from a different perspective than that of traditional socio-spatial studies and focuses on how social structure shapes other elements of the morphological character as well in addition to housing. To do so, certain aspects of social structure and morphological character are selected. These are cultural diversity, family type, income level and ownership status on behalf of social structure and land use type, land cover, building type, building layout, settlement type, settlement pattern, street pattern and commercial pattern regarding morphological character. Following, a specific case area is chosen - Kadıköy historical city center in Istanbul, Turkey -, and data is gathered accordingly. The reasons behind choosing Kadıköy historical city center are: (1) it is not well-known when compared to Historical Peninsula and Galata even though it is much older than these settlements; (2) it has a palimpsest character with a variety of data embedded in each layer of its historical development regarding the change in socio-space; (3) currently, it is one of the largest subcenters of Istanbul. However, the case area came with a problematic to be solved. Long historical data regarding socio-spatial change was kept as written or visual documents rather than in a statistical database. Only the data of the recent past with the proclamation of the republic in 1923 is started to be kept as statistical data, and even some data is missing and not accurate or trackable. So, it was intended to solve these common problems of empirical studies by creating a basic database which is mainly prepared by turning all kind of available written or visual data into categorical data to enable making analysis for understanding the effect of social structure on the morphological character of the city. The measures used draw primarily on original maps (1906, 1922 and 1938), 1946, 1970, 1982 and 2020 aerial photographs, 2007-dated base map, and memorial narratives as primary sources, 1965 plan and historical studies as secondary sources. Categorical regression (CATREG) is used to examine the relationships between social structure and morphological character, and results of the analysis is delivered to open a discussion. In summary, this study aims to understand the relationship between social structure (cultural 
diversity, family type, income level and ownership status) and morphological character (land use type, land cover, building type, building layout, settlement type, settlement pattern, street pattern and commercial pattern) based on socio-spatial theory. Since this study covers multi-variables of social and morphological features, it provides an opportunity to better understand the social structure and the morphological character as previous studies remained limited to explain.

\section{Case Area: Kadıköy Historical City Center}

Halkedon located in between Moda Cape and Haydarpaşa Meadow was first inhabited by trade colonies in 1000 B.C. due to its being a natural port close to valuable agricultural lands and water resources (Ayvazoğlu, 2011; Ekdal, 1997; Kavukçuoğlu, 2010). During centuries, it served as a homeland for Byzantine Empire (Khalkedon), Ottoman Empire (Kadı Köyü), and today, for Turkish Republic (Kadıköy). Passing through different political powers, it gained a rich multicultural and cosmopolitan character. Today, it is one of the important subcenters in Istanbul metropolitan area.

Different aspects of change react to changing circumstances at different rates. It is therefore critical to define the time scale by which change is measured (Lupton \& Power, 2004). The oldest visual documentation which shows the very first settlement of the nineteenthcentury modern era dates back to 1835 Map by B. du Bocage and J. Denis (URL-1), but, the historical core of Kadıköy that still exists today dates back to 1880s (URL-2) due to the fires in 1856 and 1878 which resulted in the very first systematized urbanization movement to start. Beginning from that point and onwards, not only the central area where the commercial activities are located changed but also, most of the natural areas left their places to urban areas to house increasing population along with Kadıköy's becoming a new city center on the Anatolian side of Istanbul. Taking these critical changes into consideration, data regarding the years between 1900 and 2020 are used for analyzing the socio-spatial change that Kadıköy historical city center has undergone (detailed explanation regarding spatial data is presented in Sect. 3).

As mentioned before, data on the case area was kept either as written or visual documents, so a systematization for keeping the track of data was highly needed. For this reason, the naming of quarters in 1938/39-dated Pervititch map is used and data is gathered on spatially-based groupings as they can easily be tracked down dating even back to 1906dated Goad map (URL-3) and after 1938/39-dated Pervititch map. According to the Pervititch map, there are fifteen main quarters in Kadıköy historical city center (see Map.1). 
Map.1 1938/39-dated Pervititch keymap for Kadıköy historical city center (modified by the authors) (URL-4)

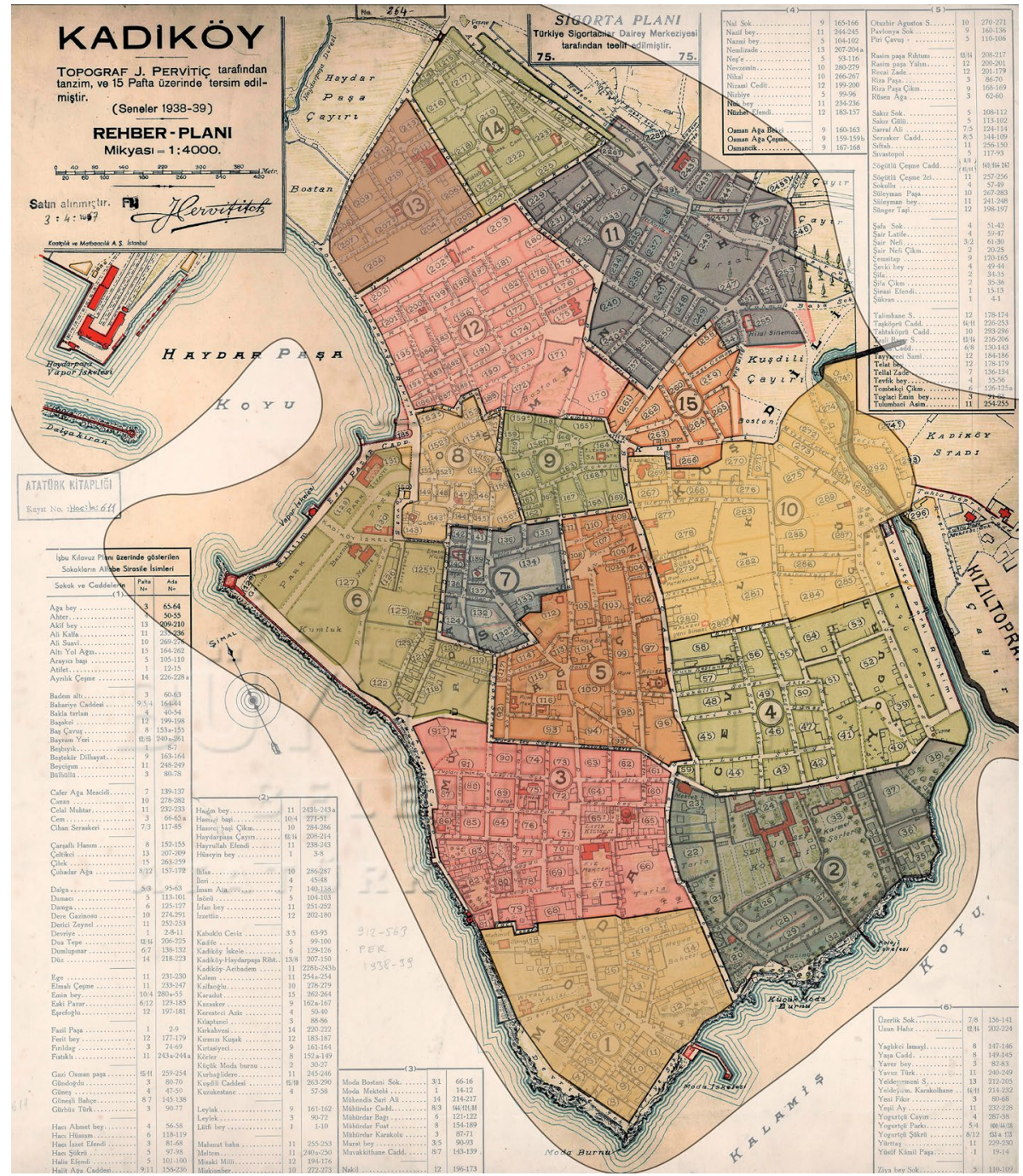

\section{Data and Methodology}

The research is built upon three main questions: (1) Which social variables (defined as cultural diversity, family type, income level, ownership status in this study) are related with which morphological variables (defined as land use type, land cover, building type, building layout, settlement type, settlement pattern, street pattern, commercial pattern in this study)?; (2) What type of relationship do they show with each other?, (3) How these results can be used to understand the socio-spatial change and what do they reveal for the future of cities?. 
Based on these research questions, a literature review is conducted to gather relevant data. In order to determine the change in morphological character considering land use type, land cover, building type, building layout, settlement type, settlement pattern, street pattern and commercial pattern, it is, first of all, benefitted from existing original maps1906 Map by C. Goad (URL-3); 1922 Map by Société Anonyme Ottomane D'études et D'entrprises Urbaines (URL-5); 1938 Map by J. Pervititch (URL-4) -, 1946-dated aerial photograph (URL-6), 1965-dated plan by Z. Teoman (URL-7), 1970 and 1982-dated aerial photographs (URL-6), 2007-dated base map and 2020-dated aerial photograph (URL-6). However, these visual documentations are only able to reflect a certain time sequence in the historical development of the case area (see Fig. 1). As the main aim of the study is to understand the change in socio-space, which is both defining a process and a causal relationship between social structure and morphological character, it is also benefitted from primary written sources to fill the gaps between these time sequences, especially for determining the change in land use type, land cover, building type and commercial pattern. These primary sources cover memory books by Aktunç (2010) and Kavukçuoğlu (2010, 2015) on quarters 1-10, Gürpınar (2009) on quarters 11-15 (see Map. 1). However, it takes time for a change in space, and in many cases, spatial patterns remain persistent (Meen, Nygaard and Meen, 2013), and it is also needed time for a change in the population composition in situ (Lupton \& Power, 2004). Hence, if no data exists for short periods between existing primary sources, it is benefitted from secondary sources for making inferences on the continuation of the existing situation. Secondary sources cover history books that are specifically focusing on this area by Ekdal (1997, 2004), Kütükçü (2014) and Türker (2008), webpages on the history of the area (URL-8; URL-9), other history books and research on Istanbul where information regarding the case area by Alus (1995), Halıcı (2008), Hizlan (2011), Tuna (2011), Satan (2012), research on local experience based on the urban renewal process in quarters 11-15 after the 2000s by an non-governmental organization (NGO) named ÇEKÜL (2014). These listed primary and secondary written sources are also used in keeping the track of the change in social structure regarding cultural diversity, family type, income level and ownership status (see Tables 1 and 2 in Sect. 3.2).

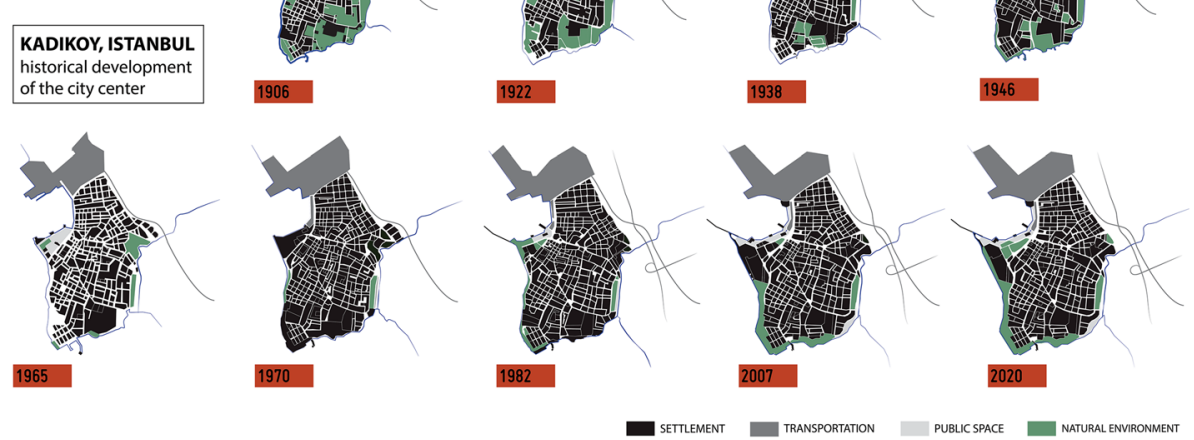

Fig. 1 Development of Kadıköy historical city center (screen digitized by the authors based on original maps (URL-3; URL-4; URL-5), aerial photographs (URL-6), 1965-dated plan (URL-7), and 2007-dated base map) 


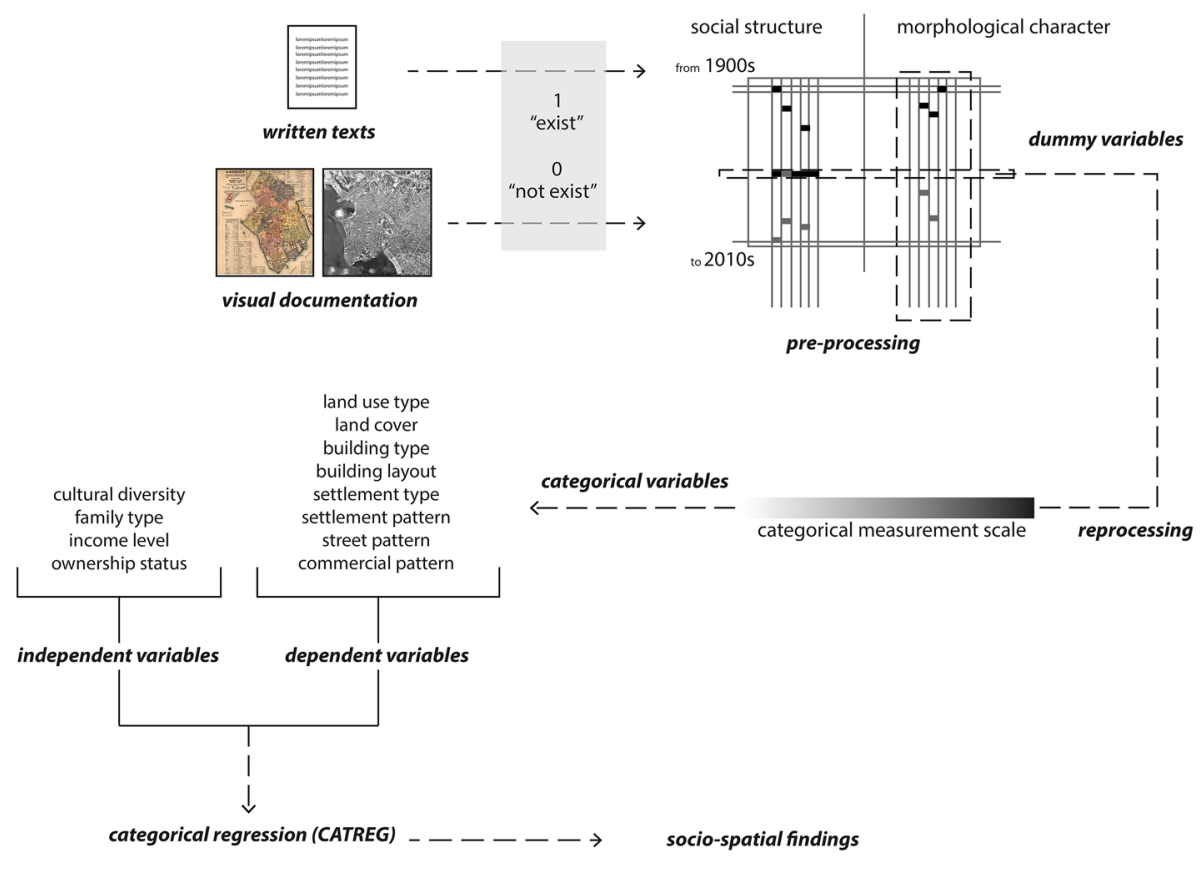

Fig. 2 Research framework and methodology

After that, a basic database is formed, and a pre-processing of data is handled to turn literal and visual data into dummy variables. Then, these variables are grouped under certain categorical independent and dependent variables for consecutive periods of ten years, standing for the dominant character of that period and quarter. By using categorical regression (CATREG), the relationship between these categorical (nominal and ordinal) variables are analyzed (see Fig. 2). In the following sections, the methods used are delivered step-by-step in detail.

\subsection{Pre-Processing Data}

Before starting the analysis, a datasheet is prepared to keep raw data that would be gathered through the literature review. This datasheet can be regarded as a basic database. On the first column, the timeline is entered, starting with 1900s and finishing with 2010s. Then, the rest of the sheet is mainly divided into two, concerning the main factors of sociospatial change under the headings of "social structure" and "morphological character". Under each factor of change, these two parts of the sheet are broken into sub-headings: "ethnicity", "family size", "income level”, "ownership status", "building typology", "construction type", "commercial uses", "recreational areas", "cultural facilities", "educational uses", "health services", "transportation facilities", "public uses", "religious uses", "natural assets", "other uses". Each item that is defined under these sub-headings are given a separate column specific to that item and the sheet is filled accordingly. While doing so, all available written and visual data are tried to be turned into dummy variables depending on the existence of any item under the social structure or morphological character for 


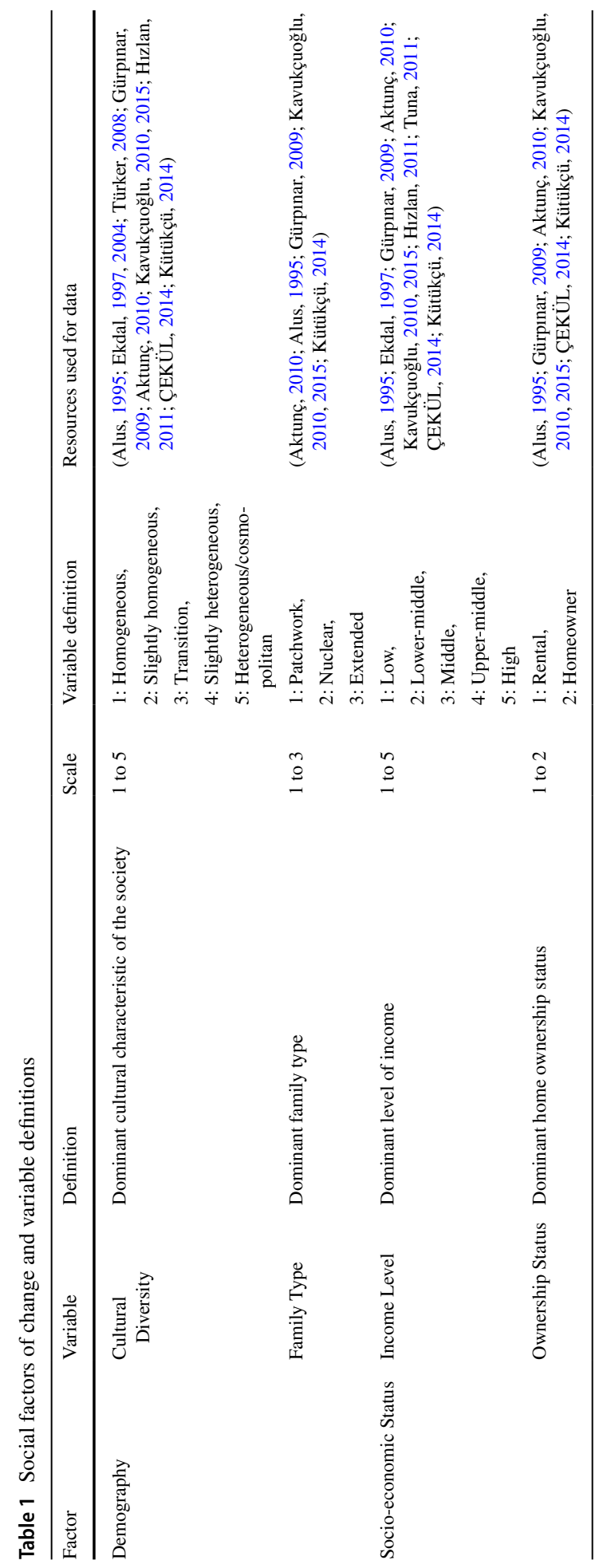




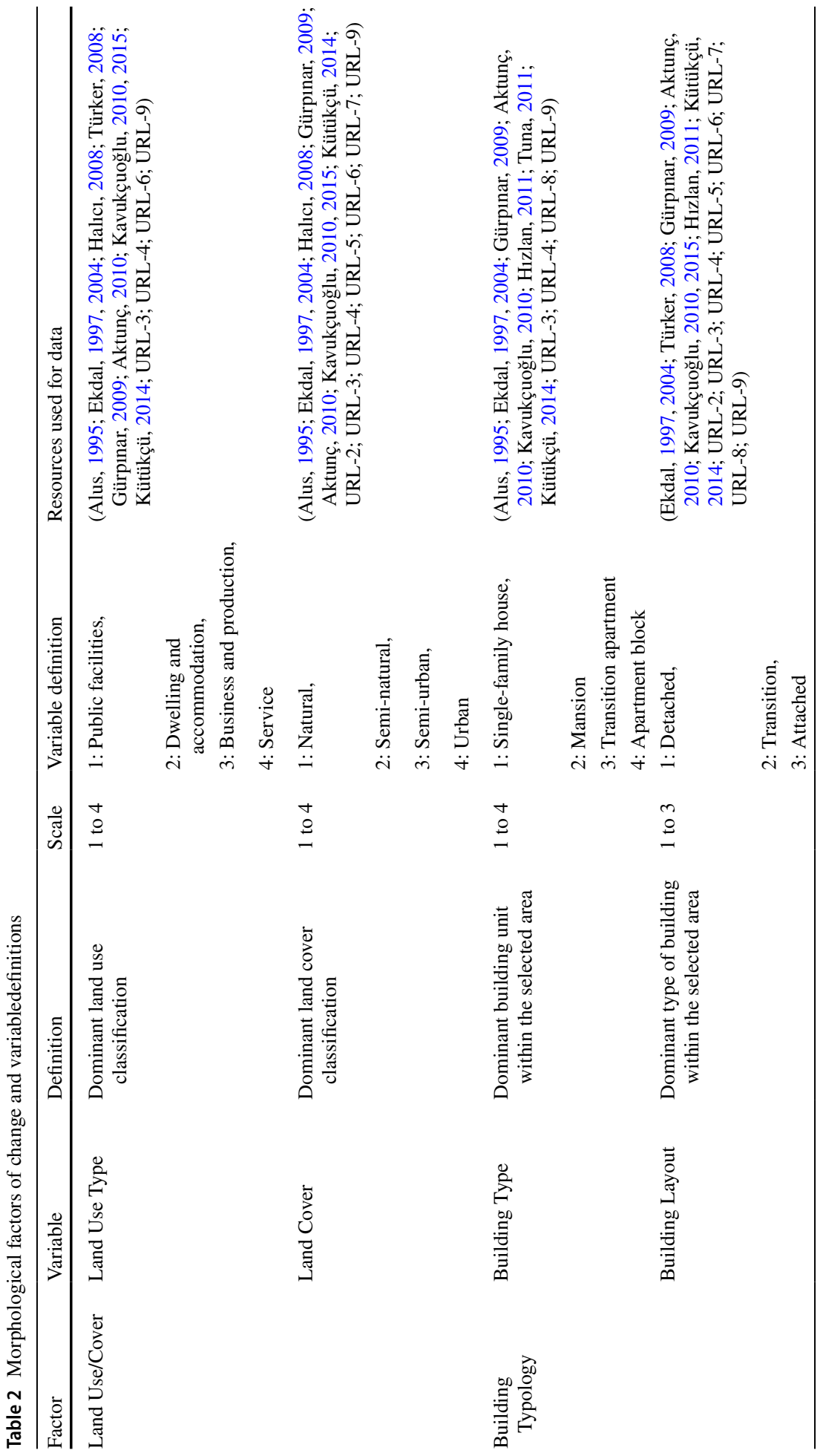




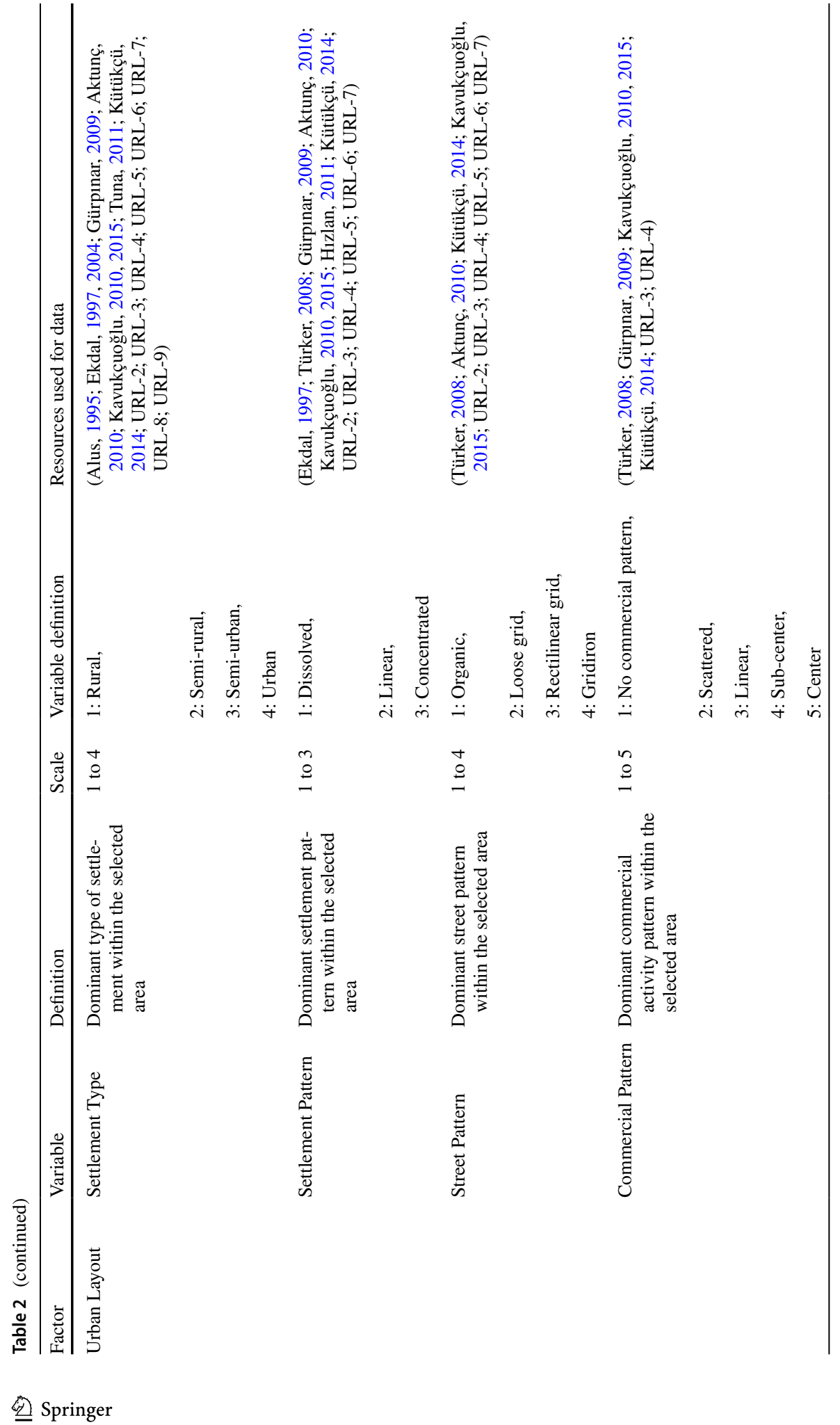


a certain period and marked as 'exist $=1$ ' and 'not exist $=0$ '. For each fifteen quarters in Kadıköy historical city center (see Map. 1), this process is repeated.

Item, here, can be defined as any kind of written or visual data that is relevant to the social structure and morphological character, such as single-family houses, middle-class workers, wooden construction, etc. This list can vary in relation to the characteristics of any case area as each would show a unique amalgamation of geography, social movements, political, economic, and environmental forces. In the case of Kadıköy historical city center, all items that are linked with society and morphology are determined while literature review and archived as a binary database within ten-years periods they belonged to in relevance with the fifteen quarters in 1938/39-dated Pervititch keymap. As a result, for each time interval, numeric data is generated that was once only kept as written text or visual source and a basic database is built.

\subsection{Reprocessing Data}

After the preparation of the database, each item that is already listed is grouped under certain variables depending on their explanatory adequacy of that variable. As the main aim of the study is to understand the relationship between social structure and morphological character from a holistic view, independent and dependent variables are defined accordingly to reveal the characteristics of these factors of socio-spatial change. While doing so, it is benefitted from literature. Depending on the nature of each independent and dependent variable, a measurement scale is defined. Going back to dummy variables kept for each time interval, dominant characteristics considering each subheading for that period are turned/merged into a measurement scale. In Tables 1 and 2, the overall variables that are taken into consideration for analysis by CATREG are listed accordingly. Cultural diversity, income level, land cover, and settlement type are defined as having ordinal measurement scale whereas the rest of the variables are regarded as nominal.

\subsection{Categorical Regression (CATREG)}

Independent and dependent variables used in this study consist of categorical data (both nominal and ordinal). Thus, categorical regression (CATREG) is chosen to evaluate the data and the relationship between these variables. "CATREG quantifies categorical data by assigning numerical values to the categories, resulting in an optimal linear regression equation for the transformed variables" (IBM, 2021). CATREG simultaneously scales nominal and ordinal variables to measure categorical variables reflecting the characteristics of the original categories at the same time. Hence, it is possible to treat these calculated variables in the same way as numerical variables. With this nonlinear transformation, it is aimed to find the best-fitting model for the transformed variables.

\section{Findings and discussion}

Null hypotheses $\left(\mathrm{H}_{\mathrm{o}}\right)$ tested by CATREG for this specific study are based on the relationship between social structure and morphological character. For each group of relationships, null hypothesis is formulated as follows: " $\mathrm{H}_{\mathrm{o}}: x$ has no effect on $y_{i}$ ", where $x$ stands for the group of independent variables ("cultural diversity", "family type", "income level" and "ownership status") and $y_{i}$ stands for the dependent variable ("land use type", "land cover", 
"building type", "building layout", "settlement type", "settlement pattern", "street pattern", "commercial pattern").

ANOVA results for each CATREG are statistically significant at $95 \%$ confidence interval (CI), and therefore, null hypotheses are rejected for each model (Table 3). Thus, it is possible to define the overall relationship between the dependent and the independent variables for each model. However, p-values show that not all relationships between explanatory variables and dependent variables can be explained at $95 \% \mathrm{CI}$ in detail. Summary of coefficients and R2 values is delivered in Table 4. According to the R2 values, $61,5 \%$ of the variance can be explained by the explanatory variables tested by CATREG model for building type. Following this comes the CATREG model for building layout with 59,7\%, settlement type with $41,9 \%$, commercial pattern with $38,6 \%$, and land use type with $32,8 \%$ of variance explained. Though with lower values, CATREG models determine 29,3\%, of variance explained for land cover, $24 \%$ for settlement pattern and $23,8 \%$ for street pattern.

Table 3 ANOVA summary

\begin{tabular}{|c|c|c|c|c|c|}
\hline & Sum of Squares & $\mathrm{df}$ & Mean Square & $\mathrm{F}$ & Sig. \\
\hline \multicolumn{6}{|c|}{ Land use type } \\
\hline Regression & 59.103 & 6 & 9.851 & 14.096 & 0.000 \\
\hline Residual & 120.897 & 173 & 0.699 & & \\
\hline Total & 180.000 & 179 & & & \\
\hline \multicolumn{6}{|l|}{ Land cover } \\
\hline Regression & 52.817 & 6 & 8.803 & 11.974 & 0.000 \\
\hline Residual & 127.183 & 173 & 0.735 & & \\
\hline Total & 180.000 & 179 & & & \\
\hline \multicolumn{6}{|c|}{ Building type } \\
\hline Regression & 110.728 & 5 & 22.146 & 55.627 & 0.000 \\
\hline Residual & 69.272 & 174 & 0.398 & & \\
\hline Total & 180.000 & 179 & & & \\
\hline \multicolumn{6}{|c|}{ Building layout } \\
\hline Regression & 107.539 & 6 & 17.923 & 42.791 & 0.000 \\
\hline Residual & 72.461 & 173 & 0.419 & & \\
\hline Total & 180.000 & 179 & & & \\
\hline \multicolumn{6}{|c|}{ Settlement type } \\
\hline Regression & 75.431 & 6 & 12.572 & 20.799 & 0.000 \\
\hline Residual & 104.569 & 173 & 0.604 & & \\
\hline Total & 180.000 & 179 & & & \\
\hline \multicolumn{6}{|c|}{ Settlement pattern } \\
\hline Regression & 43.256 & 8 & 5.407 & 6.762 & 0.000 \\
\hline Residual & 136.744 & 171 & 0.800 & & \\
\hline Total & 180.000 & 179 & & & \\
\hline \multicolumn{6}{|c|}{ Street pattern } \\
\hline Regression & 42.767 & 7 & 6.110 & 7.657 & 0.000 \\
\hline Residual & 137.233 & 172 & 0.798 & & \\
\hline Total & 180.000 & 179 & & & \\
\hline \multicolumn{6}{|c|}{ Commercial pattern } \\
\hline Regression & 69.553 & 8 & 8.694 & 13.461 & 0.000 \\
\hline Residual & 110.447 & 171 & 0.646 & & \\
\hline Total & 180.000 & 179 & & & \\
\hline
\end{tabular}




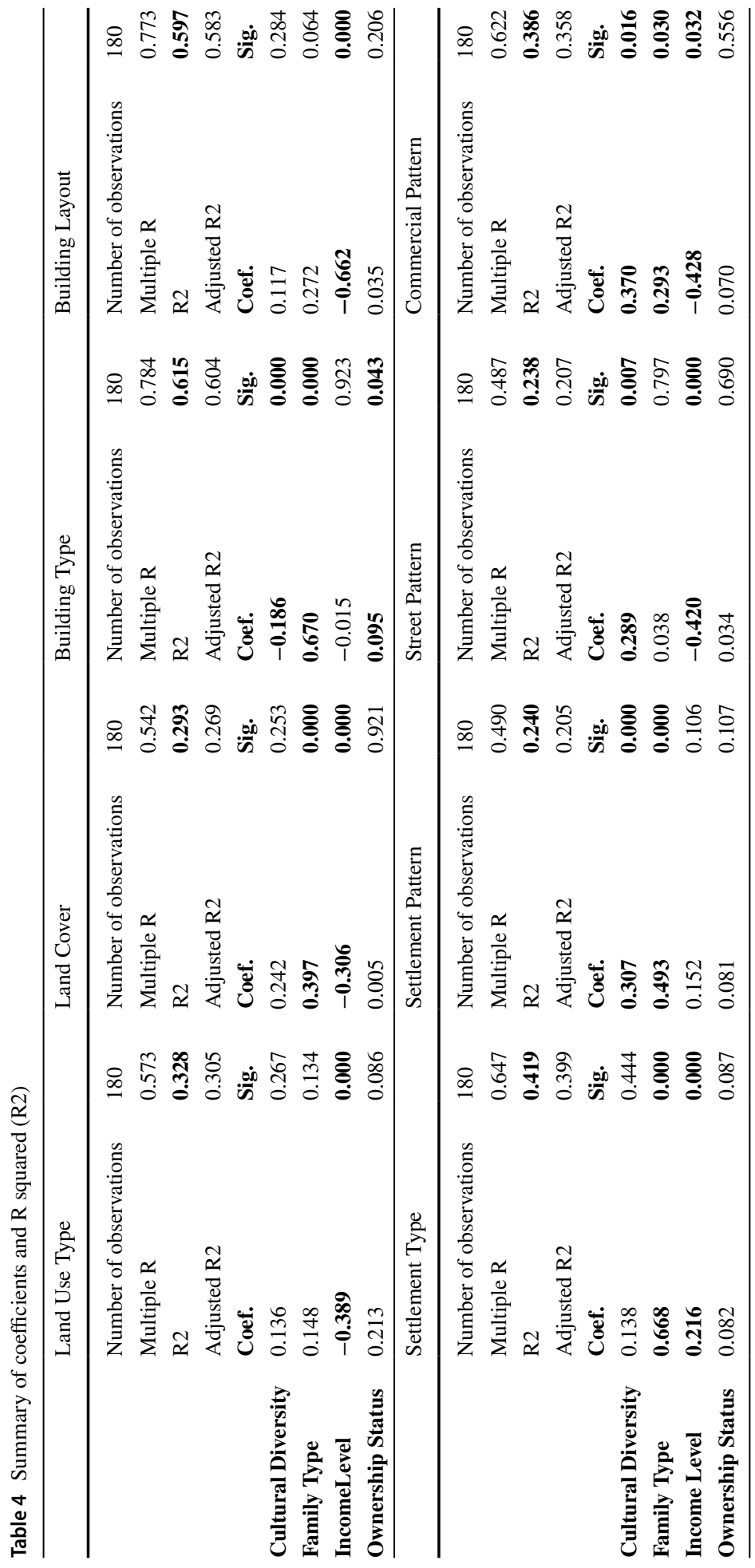


However, as discussed (Minitab Blog Editor, 2013; Corporate Finance Institute, 2021; Frost, 2021), low values of R2 does not indicate a bad fit for the model. Even, it is normal to expect low values of R2 in exploratory research especially in social sciences.

Results of the study are delivered in detail consecutively and summarized in Fig. 3.

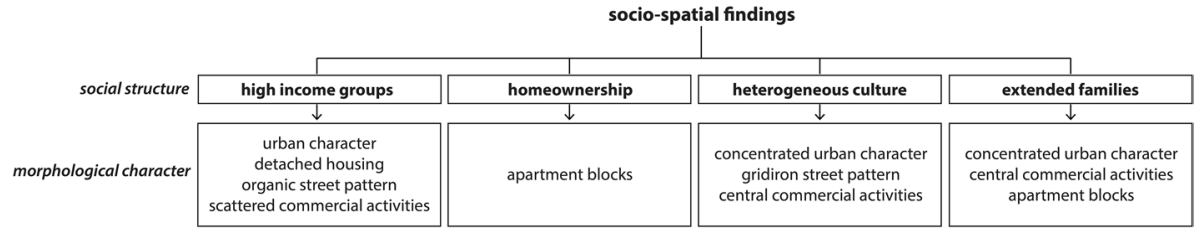

Fig. 3 Socio-spatial findings of the study

Change in Land Use Type: The relationship between "income level" and "land use type" is statistically significant at $95 \%$ CI. Interpreted coefficients show that land use type is negatively related to income level with a value -0.389 . This result shows that while income level increases land use type tends to get lower values within the measurement scale. In other terms, high income groups are merely related with residential areas and public facilities. On the other hand, low-income groups tend to settle down in or near to service or business and production areas, where they can find housing with low rates of rent.

Change in Land Cover: The relationships between "family type", "income level" and "land cover" are statistically significant at 95\% CI. Interpreted coefficients show that land cover is positively related to family type with a value 0.397 , however, negatively related to income level with a value -0.306 . In other words, it is more possible to find extended families living in the densely built areas, in other words built-up environments with extremely low green areas. However, the pattern/effect of income level continues as in the case of land use type. In more urban characteristic places, inhabitance by low-income groups is expected to be high.

Choice of Building Type: The relationships between "cultural diversity", "family type", "ownership status" and "building type" are statistically significant at 95\% CI. Interpreted coefficients show that building type is positively related with family type and ownership status with values of 0.670 and 0.095 . On the other hand, it is negatively related to cultural diversity with a value -0.186 . Among all, family type has the strongest effect on choice of building type. Hence, it is more probable to see extended families in apartment blocks. And, though with a lower probability, home ownership is closely related with living in an apartment block. However, in apartment blocks, cultural diversity decreases, and starts to become homogeneous.

Choice of building layout: The relationship between "income level" and "building layout" is statistically significant at $95 \%$ CI. Interpreted coefficients show negative relationship with a value -0.662 between income level and building layout meaning that higher income groups prefer settling in detached housing areas.

Change in Settlement Type: The relationships between "family type", "income level" and "settlement type" is statistically significant at $95 \%$ CI. Interpreted coefficients show that settlement type is positively related to family type and income level with values of 0.668 and 0.216 . As can be derived from the results, family type is an important driver for change in settlement type. The results of the CATREG for analysis of the relationship between social structure and change in settlement type is similar to the results of the analysis regarding change in land cover. 
Change in Settlement Pattern: The relationships between "cultural diversity", "family type" and "settlement pattern" are statistically significant at 95\% CI. Interpreted coefficients show that settlement pattern is positively related to cultural diversity and family type with values of 0.307 and 0.493 . While cultural diversity increases and becomes cosmopolitan, settlement pattern tends to concentrate. It can also be derived out that extended families are settled down in these densely built areas.

Change in Street Pattern: The relationships between "cultural diversity", "income level" and "street pattern" are statistically significant at 95\% CI. Interpreted coefficients show that street pattern is positively related to cultural diversity with a value 0.289 , and negatively related to income level with a value -0.420 . In other words, gridiron pattern is positively related to higher cultural diversity- in other words, cosmopolitan society-, whereas it is negatively related to high income level. Historical background of the case area shows that the aforementioned systematized urbanization movement and choice of gridiron street pattern are closely related to the existence of multicultural society.

Change in Commercial Pattern: The relationships between "cultural diversity", "family type", "income level" and "commercial pattern" are statistically significant at 95\% CI. Interpreted coefficients show that commercial pattern is positively related to cultural diversity with a value 0.370 and to family type with a value 0.293 . However, it is negatively related to income level with a value -0.428 . If cultural diversity increases, commercial activities tend to centralize. In other words, it concentrates around a center. In these central areas low-income groups and extended families are settled down.

CATREG model results show that most of the drawbacks on data is managed as all models are statistically significant at $95 \%$ CI, however, not all relationships between variables are. This shows that there are other variables that interfere with the model so that the selected explanatory variables are at some point not able to explain the variance. However, as this is an explanatory research on the relationship between social structure and morphological character based on a case study, this low values of R2 or goodness-of-fit values are somehow acceptable. Additionally, the models for building type, building layout, and settlement type have quite high R2 values for social sciences. It is possible to overcome the problem of low $\mathrm{R} 2$ by adding more explanatory variables to the model depending on the availability of the data, or, running the model again by extracting some of the variables. However, as this study is based on revealing the relationship between a predefined group of variables defining the social structure and the morphological character, this is not preferred. It is also possible to test for dual relationships between the variables by ANOVA. However, as aforementioned, such solutions are not used.

\section{Conclusion}

This study tries to explain the phenomenon of socio-spatial change by investigating the effect of social structure on the morphological character in a specific case area which is Kadıköy historical city center in Istanbul, Turkey. Cultural diversity, family type, income level and ownership status are used to represent the social structure, whereas, for morphological character it is benefitted from land use type, land cover, building type, building layout, settlement type, settlement layout, street pattern and commercial pattern. The measures used draw primarily on original maps, aerial photographs, base map, and memorial narratives as primary sources, plan, and historical studies as secondary sources. 
Relationships between explanatory variables and dependent variables are examined by categorical regression (CATREG) analysis.

One of the limitations of the research was to systematically collect and standardize data by looking at an exceptionally long historical background of over a hundred years. Unfortunately, not all parameters representing both social structure and morphological character that were derived from the literature were accessible. Due to this reason, they were excluded from the analysis. Another limitation in the research was the scarcity of measurable materials such as maps and socio-demographic data throughout all periods of research and the lack of similar quality data from the same period. All these deficiencies were tried to be eliminated by comparative research from primary and secondary resources on visual and written data. After literature review, by converting pre-processed binary data based on existing available written and visual documentation to categorical data, it is made possible to test the hypotheses by CATREG. By this, it is aimed to put forward an alternative way of measuring socio-spatial change through categorical data (nominal and ordinal) and testing the hypothesized relationships between selected aspects of social structure and morphological character.

First of the results obtained in the study is that heterogeneity in the society is merely a trigger for concentrated central areas. As cultural diversity increases, the clustering pattern of the settlement increases. Likewise, commercial areas turn into a more concentric pattern. The increase in cultural diversity brings more compact and well-defined commercial centers with gridiron street pattern. Vice versa, in densely populated and built areas of urban land dominated with commercial activities, cultural diversity is high. Especially, in the case of Kadıköy historical city center, this is also linked with the gridiron street pattern which is actually brought as a planning and design measure by the foreigner inhabitants of the area. It is also observed that today's apartment blocks are characterized by homogeneity in the society.

The second result of the study is on the effects of the family type. It is found out that extended families tend to live in apartment blocks located in concentrated central urban areas. This shows how mixed-use plays a critic role for extended families to settle down in an area.

As a third result, it is found out that residential areas with more green space and natural areas are preferred by high income groups. These areas are dominated by detached housing with organic or loose grid street pattern. In addition to this, commercial activities are scattered and dissolved in these areas. However, this picture does not indicate for suburban areas. In contrast, it stands for urbanity. These results suggest for the search for quality of living by higher income groups where they can reach certain infrastructure, open space, and privacy within the urban area.

Finally, the impact of the ownership status on the morphological character presents a relationship pattern that is only limited to the choice of building type. Most of the time, from a structuralist point of view, choice of housing type is closely being related with income level, in other words, the ability to buy or spend money, and regarded as an important factor for the housing sector. To some extent, home ownership can also be discussed as a sign for ability to buy, although income level is not found as being one of the significant factors for choice of building type. At least, it can be claimed that home ownership is high in apartment blocks.

The findings obtained from the study mostly confirm the previous empirical studies made. It is also clear that there is much more work to be done on the measurement and the analysis of the relationship between ownership status and the selected aspects of the morphological character. However, different than those preliminary studies, in this study, 
change in social structure and morphological character is presented relationally between multiple variables by looking from a wider perspective to understand urban areas without only focusing on housing issues but also considering other urban elements as well. Though based on qualitative indications of how several aspects of change are linked to another referring to the theoretical framework of socio-spatial dialectic, the effects of these variables are also demonstrated quantitatively through analysis by categorical regression (CATREG).

Most of the time, research covering long periods of time is tried to be avoided due to limitations in availability of data, or due to type of data stored as it will take a long time and effort to deal with this data. However, these limitations seem to be an important drawback for revealing certain relationships among socio-spatial change. Hence, with this research, such barriers are tried to be overcome, and provide insight for other researchers dealing with the same problematic.

Supported by many empirical studies, it is important to explain socio-spatial change for localities through the effects of socio-economic variables on urban space in periods from past to present to understand today and to take action for the future. There are certainly specific cycles or breaking points that societies and spatial development processes experience which ease envisioning of such circumstances to happen and to be oriented. However, as can be seen from the model results in this study, it is not possible to fully explain sociospatial change at all its aspects (this is not expected anyway).

It should not be forgotten that the dynamics that are effective in socio-spatial change can also modify themselves. Technological developments reorient the relationships of individuals with each other and their socialization preferences depending on the place. New terms such as acceleration society, instantaneous time, interspaces, and etc. related with this change driven by technology reveal the quickly changing dynamics and systems, and can be summarized as socio-technological factors. Apart from developments in technology and its adaptation, climate change, energy dependence, and global pandemics (such as COVID-19) are emerging as new phenomena expected to be effective in socio-spatial change in the near future. And these dynamics seem to define/shape urban space much faster than the change of social structure as the change in social structure takes longer time to settle and be reflected in the urban area, or it might be limited to a group of people as in the case of social segregation. Nevertheless, it will be possible to monitor the effect levels of the factors that affect socio-spatial change only with long-term studies, which will in return serve as a tool for local governments in decision-making processes, as well as for designers and planners on the stage of design.

This study attempts to create a ground for discussion for future studies on socio-spatial dialectics as it aims to put forward new ways for analysis, but its limitations must be acknowledged. The measurement of the effect of the social structure remains crude in some respects and incomplete depending on the aforementioned limitations. However, it is intended to overcome the problem of availability of data for long-term change studies and to open a new discussion on how new methodologies could be developed for making the maximum out of existing limited data.

Acknowledgement This research is part of an on-going doctoral dissertation of the corresponding author Aslı Ulubaş Hamurcu, supervised by Prof. Dr. Fatih Terzi (the co-author of the paper).

Authors' contributions All authors contributed to the study, read and approved the final manuscript.

Funding No funds, grants, or other support was received. 
Data availability All data and materials used for research are clearly identified within the text.

\section{Declarations}

Conflict of interest The authors have no conflicts of interest to declare that are relevant to the content of this article.

\section{References}

ÆrØ, T. (2006). Residential choice from a lifestyle perspective. Theory and Society, 23(2), 109-130. https:// doi.org/10.1080/14036090600773139

Aktunç, H. (2010). Bir Kadıköy'oğlu (11th ed.). Heyamola Yayınları.

Alus, S. M. (1995). İstanbul Kazan Ben Kepçe. İletişim Yayınları.

Andersson, R. (1998). Socio-spatial dynamics: Ethnic divisions of mobility and housing in post-palme Sweden. Urban Studies, 35(3), 397-428. https://doi.org/10.1080/0042098984835

Appelbaum, R. P. (1970). Theories of social change. Markham Publishing Company.

Ayvazoğlu, B. (2011). İstanbul Kültür ve Estetiği. In A. E. Bilgili (Ed.), Şehir ve Kültür: İstanbul. Profil Yayıncilık.

Beamish, J. O., Goss, R. C., \& Emmel, J. (2001). Housing and society lifestyle influences on housing preferences. Housing and Society, 28(1-2), 1-28. https://doi.org/10.1080/08882746.2001.11430459

ÇEKÜL (2014). Yeldeğirmeni Deneyimi: Kentsel Yenilemeye Farklı Bir Yaklaşım. Stil Matbaacılık.

Corporate Finance Institute (2021). What is R-Squared? Retrieved February 9, 2021, from https://corpo ratefinanceinstitute.com/resources/knowledge/other/r-squared/\#: :text=R-Squared $\left(\mathrm{R}^{2}\right.$ or the,that is changed in order

Coser, L. A. (1967). Continuities in the study of social conflict. Free Press.

Davis, K. (1950). Human society. Macmillan.

Ekdal, M. (1997). Bizans Metropolünde İlk Türk Köyü Kadıköy. Kadıköy Belediye Başkanlı̆̆ı Kültür Yayınları.

Ekdal, M. (2004). Kapalı Hayat Kutusu: Kadıköy Konakları. Yapı Kredi Yayınları.

Földi, Z., \& Kovács, Z. (2014). Neighbourhood dynamics and socio-spatial change in Budapest. Europa Regional, 19, 7-20.

Frost, J. (2021). How to Interpret P-values and Coefficients in Regression Analysis. Retrieved February 9 , 2021, from https://statisticsbyjim.com/regression/interpret-coefficients-p-values-regression/

Gaffney, C. (2010). Mega-events and socio-spatial dynamics in Rio de Janeiro, 1919-2016. Journal of Latin American Geography, 9(1), 7-29.

Gürpınar, M. (2009). Çamlıca'dan Yeldeğirmeni'ne Rüzgarın Peşinde. Heyamola Yayınları.

Halıcı, G. (2008). Acem'in Kahvesi. In İstanbul'un Anadolu Yakasında Tarihsel Bir Gezinti. ÇIMSA Yayınları.

Hızlan, D. (2011). Türkiye'deki Sosyal Değişimlerin Sembolü Olarak Edebiyatta İstanbul. In A. E. Bilgili (Ed.), Şehir ve Kültür: İstanbul. Profil Yayınc1lık.

IBM (2021). Categorical Regression (CATREG). Retrieved February 6, 2021, from https://www.ibm.com/ support/knowledgecenter/SSLVMB_sub/statistics_mainhelp_ddita/spss/categories/idh_catr.html

Kavukçuoğlu, D. (2010). Mühürdar'dan Moda'ya Geçmişe Doğru Bir Gezinti. Heyamola Yayınları.

Kavukçuoğlu, D. (2015). Moda'da Gezinti. Can Yayınları.

Kütükçü, T. (2014). Kadıköy'ün Kitabı. (2nd ed.). Ötüken Yayınları.

Li, Z., \& Wu, F. (2006). Socio-spatial differentiation and residential inequalities in Shanghai: A case study of three neighbourhoods. Housing Studies, 21(5), 695-717. https://doi.org/10.1080/026730306008073 65

Lupton, R. and Power, A. (2004). What we know about neighbourhood change: a literature review. CASEreport, 27. London. Retrieved September 10, 2020, from http://eprints.lse.ac.uk/27357/1/What_we_ know_about_neighbourhood_change_(LSERO_version).pdf

Marcinczak, S., \& Sagan, I. (2011). The Socio-spatial Restructuring of Łódz’ Poland. Urban Studies, 48(9), 1789-1809. https://doi.org/10.1177/0042098010379276

Marcuse, P. (1993). What's so new about divided cities? International Journal of Urban and Regional Research, 17(3), 355-365.

Martin, G. P. (2005). Narratives great and small: Neighbourhood change, place and identity in notting hill. International Journal of Urban and Regional Research, 29(1), 67-88. https://doi.org/10.1111/j.14682427.2005.00570.x 
Masoumi, H. E., Terzi, F., \& Serag, Y. M. (2019). Neighborhood-scale urban form typologies of large metropolitan areas: Observations on Istanbul, Cairo, and Tehran. Cities, 85, 170-186. https://doi.org/10.1016/j.cities.2018. 09.005

Meen, G., Nygaard, C., \& Meen, J., et al. (2013). The causes of long-term neighbourhood change. In M. van Ham (Ed.), Understanding neighbourhood dynamics: New insights for neighbourhood effects research. Springer.

Minitab Blog Editor (2013). Regression Analysis: How Do I Interpret R-squared and Assess the Goodness-of-Fit? Retrieved February 9, 2021, from https://blog.minitab.com/blog/adventures-in-statistics-2/regression-analy sis-how-do-i-interpret-r-squared-and-assess-the-goodness-of-fit

Ozdemir, I. M., \& Gencosmanoglu, A. B. (2007). Metamorphism in culture and housing desing: Turkey as an example. Building and Environment, 42(3), 1445-1452. https://doi.org/10.1016/j.buildenv.2005.12.007

Peters, P. A., \& Skop, E. H. (2007). Socio-spatial segregation in Metropolitan Lima Peru. Journal of Latin American Geography, 6(1), 149-171.

Rapoport, A. (1969). House form and culture. Prentice Hall.

Relph, E. (1976). Place and placelessness. Pion.

Rodríguez, A., Martínez, E., \& Guenaga, G. (2001). Uneven redevelopment: New urban policies and socio-spatial fragmentation in metropolitan Bilbao. European Urban and Regional Studies, 8(2), 161-178. https://doi.org/ $10.1177 / 096977640100800206$

Satan, A. (2012). İstanbul'un 100 Yıll. İstanbul Büyükşehir Belediyesi Kültür A.Ş.

Soja, E. W. (1980). The socio-spatial dialectic. Annals of the Association of American Geographers, 70(2), 207225. https://doi.org/10.1111/j.1467-8306.1980.tb01308.x

Soja, E. W. (1989). Postmodern geographies, the research of space in critical social theory. Verso.

Strasser, H., \& Randall, S. C. (1981). An introduction to theories of social change. Routledge \& Kegan Paul.

Sykora, L. (1999). Processes of socio-spatial differentiation in post-communist prague. Housing Studies, 14(5), 679-701. https://doi.org/10.1080/02673039982678

Tuna, K. (2011). İstanbul'un Sosyolojik Dönüşümü. In A. E. Bilgili (Ed.), Şehir ve Kültür: İstanbul. Profil Yayıncilik.

Türker, O. (2008). Halkidona'dan Kadıköy'e: Körler Ülkesinin Hikayesi. Sel Yayıncılık.

URL-1 Plan von Constantinopel und seinen Vorstädten diesseits und jenseits des Bosporos. Retrieved May 14, 2020 from http://digitool.is.cuni.cz:1801/view/action/error.do;jsessionid=AF30ADCF63DE87D5A543 D91C5D275013.

URL-2 Constantinople, Turkey 1882. Retrieved May 14, 2020 from https://collections.lib.uwm.edu/digital/colle ction/agdm/id/1017/.

URL-3 Constantinople vol. III Kadi-Keui / Chas. E. Goad - 1906. Retrieved May 14, 2020 from https://galli ca.bnf.fr/services/engine/search/sru?operation $=$ searchRetrieve $\&$ version $=1.2 \& q u e r y=\% 28 \mathrm{gallica}$ all $\% 22$ Kadi-Keui $\% 22 \% 29 \&$ lang=en\&suggest $=0$.

URL-4 İstanbul Kadıköy Sigorta Planı. Retrieved May 14, 2020 from http://ataturkkitapligi.ibb.gov.tr/ataturkkit apligi/index.php.

URL-5 Harvard Map Collection. Retrieved May 14, 2020 from https://ids.lib.harvard.edu/ids/view/15497126? buttons $=\mathrm{y}$.

URL-6 Uydu Fotoğraflarl. Retrieved May 14, 2020 from https://sehirharitasi.ibb.gov.tr/.

URL-7 Harita Kadıköy İlçesi. Retrieved May 14, 2020 from https://www.modamuzayede.com/urun/348784/harita-kadikoy-ilcesi.

URL-8 Geçmişin Modern Mimarisi - 1: Kadık̈̈y - Arkitera. Retrieved May 14, 2020 from https://www.arkitera. com/haber/gecmisin-modern-mimarisi-1-kadikoy/

URL-9 atılgan blog. Retrieved May 14, 2020 from http://atilganblog.blogspot.com/

van Criekingen, M. (2010). "Gentrifying the re-urbanisation debate", not vice versa: The uneven socio-spatial implications of changing transitions to adulthood in Brussels. Population, Space and Place, 16, 381-394. https://doi.org/10.1002/psp.582

van Ham, M., et al. (2013). Understanding neighbourhood dynamics: New insights for neighbourhood effects research. In M. van Ham, et al. (Eds.), Understanding neighbourhood dynamics: New insights for neighbourhood effects research (pp. 1-21). Springer.

Walks, R. A. (2001). The social ecology of the post-fordist/global city? Economic restructuring and sociospatial polarisation in the Toronto Urban Region. Urban Studies, 38(3), 407-447. https://doi.org/10.1080/00420 980120027438

Publisher's Note Springer Nature remains neutral with regard to jurisdictional claims in published maps and institutional affiliations. 